\title{
The Coronavirus Transmission by Wastewater and Biosolids Reuse for Agricultural Usages: A Literature Review
}

\author{
Ahmad Sabzali* \\ PhD of Environmental Health, Isfahan University of Medical Science, Iran
}

*Corresponding author: Ahmad Sabzali, PhD of Environmental Health, Isfahan University of Medical Science, Iran.

To Cite This Article: Ahmad Sabzali. The Coronavirus Transmission by Wastewater and Biosolids Reuse for Agricultural Usages: A Literature Review. 2020 - 8(5). AJBSR.MS.ID.001302. DOI: 10.34297/AJBSR.2020.08.001302.

Received: 眥 April 10, 2020; Published: 畊 April 23, 2020

\begin{abstract}
One of the important alternative water source of water is treated effluent from wastewater treatment plant that may be used in the agricultural sectors. Reused wastewater depending on the treatment method may contain various contaminants, including microbial contaminants. In most countries, fecal coliforms are used as a good indicator of microbial contamination control and viral contamination is not analyzed. In this study, the probability of COVID-19 outbreaks with reusing treated effluent from wastewater treatment plant was evaluated. According to this study, irrigation of the agricultural products with treated effluents or spreading biosolids on farm lands may be one of the ways of transmission of the COVID-19 disease.
\end{abstract}

Keywords: COVID-19; Treated wastewater; Irrigation; Biosolid

\section{Introduction}

In recent years treated municipal wastewater is one of the important alternative water source of water in water-scarce regions. In addition to water reuse, the process may be the only way for effluent management in regions with disposal problems [1]. The quality of treated wastewater depends on the quality of the municipal water supply, nature of the wastewater, the degree of treatment the wastewater, nominal capacity and influent hydraulic loading and the by-passes. Microbial analysis of some treated municipal wastewater revealed that E. coli in the treated wastewaters exceeded health standards [1]. Municipal wastewaters can be reclaimed and reused directly or indirectly. In direct reuse, the treated municipal wastewater is reused immediately after treatment [2].

Reused wastewater depending on the treatment method may contain various contaminants, including viral contaminants.

Environmental and health risks associated with reuse of wastewater for irrigation include:

a. Farmers and farm workers may be directly exposed to pathogens [3]. b. Consumption of produce, especially vegetables, from wastewater irrigated farms poses an additional pathway for transmission of pathogens from wastewater to the general public [3].

c. Living organisms in the soil may be affected [4].

Different types of pathogenic viruses are shed in human faeces (>109/g), which can infect humans and many other vertebrates. Five groups of pathogenic excreted viruses are particularly important: adenoviruses, enteroviruses, hepatitis A virus, reoviruses and diarrhoea-causing viruses [5]. Previous research has revealed that animal viruses are uncommon in healthy human feces and are limited to picobirnavirus (PBV, 733 clones). PBV belongs to a recently identified family of RNA viruses with bisegmented genomes, which are present in the stools of humans and animals [6].

Some environmental factors affect virus survival, including temperature, humidity and virus type, the presence of organic material, sunlight or antiviral chemicals [7]. At low temperatures, viruses may survive for extended periods of time and sometimes 
for several years. At higher temperatures, the viral population will be reduced by several orders of magnitude in a few days [8]. The presence of pollution especially organic matter in water has a positive impact on virus survival. The persistence of viruses in polluted waters is related to protective effect of water impurities such as suspended solids. Solid associated viruses in wastewater effluents are discharged into aquatic environments and accumulate in the sediments where they persist longer than in the water column [9].

Survival times of enteroviruses at $20-30^{\circ} \mathrm{C}$ in sewage, in soil and on crop surfaces are 50-120 days, 20-100 days and15-60 days, respectively [4]. Recent findings by scientists have shown that the coronavirus can be present in the patient's faeces. A new study led by Chinese scientists reveals that sputum had a viral load of 3.2 million per ml. The viral load for faeces and deep throat saliva was 12,000 and 10,000 respectively for every $\mathrm{ml}$ [10].

Since the physical and biochemical properties of COVID-19 and SARS are similar, the data collected from SARS experiments can be used for COVID-19. According to these experiments, the virus can survive in the faeces at $20^{\circ} \mathrm{C}$ for 3 days and in the urine for 17 days [11]. There is little data about the survival time of the virus in sewage. The previous researches about SARS have shown the virus survive in the wastewater for 2-4 days [12].

The COVID-19 pandemic which started in Wuhan, China, in December, has now spreads across the globe. The COVID-19 is an infectious disease caused by a new virus. The virus is mainly spread during close contact and through respiratory droplets produced when those infected people cough, sneeze or talk $[11,13]$. The purpose of a literature review is to provide foundation of knowledge about the risk of COVID-19 transmission by reusing wastewater and biosolids.

\section{The Coronavirus Transmission via Irrigation}

According to the latest research the main route of transmission for COVID-19 is close contact with infected people [14]. This may be the main route, but it's not the only route. New research has suggested that along with respiratory system, digestive system is a potential routes for 2019-nCov infection. In fact the study revealed that similar to SARS-CoV and MERS-CoV, 2019-nCov enters into host cells via cell receptor angiotensin converting enzyme II (ACE2) [15].

The survival ability of COVID-19 in wastewater is unclear. During infectious disease outbreaks, more detergents are consumed which can be present in the wastewater at a lower concentration. It has shown that virus survival decreased with increasing detergent concentration in wastewater. Although the exact mechanism is not clear, but some findings suggest that the fatty acids and their monoesters are incorporated into the lipid membrane, causing destabilization of the bilayer $[12,16]$.
Based upon studies conducted over SARS outbreaks, the duration of persistence of viable coronavirus in environment is affected by temperature, humidity, level of organic matter, and presence of antagonistic bacteria especially aerobic microorganisms and protozoa. Increase in the wastewater temperature from $23^{\circ} \mathrm{C}$ increases the virus inactivation mainly caused by denaturation of proteins and increased activity of extracellular enzymes [12,17]. There is not enough knowledge about the performance of septic tanks for inactivation of COVID-19. Due to the lack of disinfection unit, viruses are not significantly inactivated in septic tanks and COVID-19 may be present in their effluent [18].

The effect of irrigation with treated wastewater on soil properties, crops yield and qualitative traits of crop products, including their microbiological safety was investigated in Southern Italy (Apulia Region) for more than 1.5 years. In the region treated wastewater after disinfection by UV radiation is used to irrigate tomato and broccoli [19]. Irrigation is important to the overall economy of the Puglia region in Italy, to especially agriculture. The total irrigated land amounted in the region was 238,546.02 ha in 2009/2010. The reused wastewater was used for irrigation of permanent crops such as olive and grape fresh-cut vegetables (broccoli, carrot, spinach, artichoke, asparagus, etc.) and processing tomatoes [20].

Vegetable crops, especially those to be consumed raw such as lettuce and irrigated by treated wastewater may be a good place for the virus to hide and to spread the disease [21].

Unfortunately by March 30, 2020 more than 10,000 death was reported from Worldometer because of COVID-19 in Italy. The highest positive cases and death has been reported in Lombardy region.

In Spain, as in other countries facing with water scarcity and drought problems, part of the wastewater treatment plant effluent is used to solve issues concerning insufficient allocation of resources to certain uses. Total wastewater reused in wastewater treatment plants operating in various cities in Spain varied $368 \mathrm{hm} 3 /$ year and $450 \mathrm{hm} 3 /$ year in 2006 . The quantity of reused wastewater is equivalent to $10.8-13 \%$ of the total treated wastewater $[22,23]$.

In most of Spain's southern regions, which face water shortages, water resources management and reusing wastewater are of paramount importance to meet future demands. In Pinedo wastewater plant $78 \mathrm{hm} 3$ /year of treated wastewater are used for irrigation crops and environmental restoration of natural parks. According to published information until 2016, more than 50\% of total treated wastewater in Valencia and Murcia regions are reused for agriculture [22,24].

In different regions of Spain, such as Valencia, Murcia, 
peninsula, and Madrid, part of required water for agricultural use, irrigation of parks and recreational areas is supplied by wastewater reusing25. In Spain, as Italy, many cases of the illness have been reported. Due to water scarcity and drought, water supplies for irrigation of farm lands in most Iranian cities are difficult [26]. In Iran, water consumption for agriculture rises to more than $80 \%$ compared to $5.8 \%$ and $1.2 \%$ for drinking and industrial consumptions, respectively. Unfortunately, most farming lands around the metropolises in Iran are irrigated illegally with wastewater treatment plant (WWTP) effluents [27]. Treated municipality wastewater treatment plants (WWTP) in cities such as Qom, Tehran and Isfahan are used legally or illegally to irrigate farm lands. The treated wastewater of the Qom WWTP, along with collected surface water from the city, is collected and channeled downstream of Qomrud and used illegally by some farmers.

\section{The Coronavirus Transmission via Biosolids}

Some countries use biosolids for agricultural use specially for improving soil fertility. In Europe, the yearly production of wasted bio-sludge from WWTP is about 10.13 million tons of dry matter (DM). About $40 \%$ of the bio-sludge is more processed and reused for soil fertility. Over $50 \%$ of produced biosolids in some European countries such as Denmark, France, Ireland, Spain and United Kingdom, are used for agriculture. In Belgium, Romania, Netherland and Greece the reuse of biosolids as soil fertilizer is very small [28]. The previous researches highlighted that after spreading of biosolids on farming lands, enteroviruses cannot survive for more than 2 weeks. Unlike enteroviruses, faecal indicators can survive in the soil for more time [29]. One of the leading countries in biosolids recovery is Italy. The total amount of reused biosludge for agricultural applications in Italy was up to $30 \%$ of total biosolids production in 2010 (1.1 million tons of dry matter). 50\% of produced bio-sludge in Lombardy is reused for agriculture (700000 t/year, 2007-2010). More than 90\% of biosolids recycling takes place in five regions of Lombardy, Emilia Romagna, Puglia, Tuscany and Veneto28. Precisely, these regions have the highest death rates because of COVID-19. This cannot be accidental.

In the U.S the facilities used to process biosolids in WWTPs such as Hunts Point WWTP are based on modern science and the final biosolid is used for agricultural usage. New York City's 14 Wastewater Treatment Plants together treat 1.3 billion gallons of wastewater daily. The wastewater treated in these treatment plants is directed to rivers and bays such as Hudson River and Jamaica Bay $[30,31]$

\section{Safety Irrigation}

A free chlorine residual of $>0.5 \mathrm{mg} / \mathrm{L}$ of free chlorine or $2.19 \mathrm{mg} / \mathrm{L}$ for chlorine dioxide in will be enough for ensuring complete inactivation of viruses. The concentration of free chlorine residual after chlorination is depended on many parameters such as $\mathrm{pH}$, temperature and ammonia concentration. Free chlorine reacts readily with remained ammonia in WWTP effluent to form chloramine compounds such as mono chloramines [32,33]. Disinfection rate with the chloramine compounds is always slower than free chlorine and then much higher dose of chlorine have to add for achieving a same effect [34,35].

The following points should be taken into consideration for safety disinfection:

a. The residual disinfectant concentration (C) and the contact time (T) must be determined for each wastewater treatment plant [36]. Since rotavirus and poliovirus are inactivated in C.T below than $15 \mathrm{mg} . \mathrm{min} / \mathrm{l}$, therefore it can be expected that COVID-19 will be inactive at the same condition [37-38].

b. The effectiveness of chlorination for viral inactivation is dependent on remained organic matter as BOD or COD and turbidity. All suspended or colloidal materials in wastewater may protect viruses from contact with chlorine. Effluent organic matter and suspended solids may provide a protective layer for viruses. According to new researches, turbidity of water make a shield for protecting viruses against disinfectants. The proposed turbidity for assuring at least three units of logarithms reduction of viruses is $\leq 5 \mathrm{NTU}$.

c. The die-off of fecal indicators in soil is depended on irrigation method. Reducing direct contact of plant with water, will limit the possible contamination of the products [19].

\section{Conclusions}

As the World Health Organization announced the COVID-19 viral disease that has swept into most countries and killed more than 13,000 people is now officially a pandemic. Now routine activity is sub-field of the disease and new strategies has substituted have replaced. Under normal conditions, the treated effluent and final biosolids of the WWTPs were used for irrigation or soil fertility. Similar to other economic and social activities, WWTPs must be operated with a new management approach. Both treated wastewater and biosolids may still contain high amounts of the viruses that will be transmitted into the environment and infect human directly or indirectly. In all countries with high positive cases, wastewater or biosolids are reused for different usages. Although stricter regulations have prevented people from being present in the community, but the COVID-19 may be transmitted unintentionally to their home along with foods and vegetables. According to this study, irrigation of the agricultural products with treated effluents or spreading biosolids on farm lands may be one of the ways of transmission of the COVID-19 disease. 


\section{References}

1. Pedrero F, Kalavrouziotis I, Alarcón JJ, Koukoulakis P, Asano T (2010) Use of treated municipal wastewater in irrigated agriculture-Review of some practices in Spain and Greece. In Agricultural Water Management 97(9): 1233-1241.

2. Ganoulis J (2012) Risk analysis of wastewater reuse in agriculture. International Journal of Recycling of Organic Waste in Agriculture 1(1): $1-9$.

3. Shakir E, Zahraw Z, Al Obaidy AHMJ (2017) Environmental and health risks associated with reuse of wastewater for irrigation. Egyptian Journal of Petroleum 26(1): 95-102.

4. Sayed Roholla Mousavi, Mohammad Taghi Tavakoli, Mohammad Dadgar, Abbas Isvand Chenari, Ahmad Moridiyan, et al. (2015) Reuse of Treated Wastewater for Agricultural Irrigation with Its Quality Approach.

5. Pathogenic viruses in human faeces, Danish Environmental Protection Agency.

6. Zhang T, Breitbart M, Lee WH, Run JQ Wei CL et al. (2006) RNA viral community in human feces: Prevalence of plant pathogenic viruses. PLoS Biology 4(1): 0108-0118.

7. Tang JW (2009) The effect of environmental parameters on the survival of airborne infectious agents. Journal of The Royal Society Interface 6(suppl_6): S737-746.

8. Pinon A, Vialette M (2018) Survival of Viruses in Water. Intervirology 61(5): 214-222.

9. Albert Bosch (2020) Human enteric viruses in the water environment: A minireview.

10. Coronavirus can be transmitted through faeces, Chinese University study confirms, with experts suggesting stool tests as alternative screening tool | South China Morning Post.

11. Taskin Tok T, Tatar G, Tugba TT (2017) Structures and Functions of Coronavirus Proteins: Molecular Modeling of Viral NucleoproteinInternational Journal of Virology \& Infectious Diseases International Journal of Virology \& Infectious Diseases 2(1): 1-7.

12. Patricia M Gundy, Charles P Gerba, Ian L Pepper (2009) Survival of Coronaviruses in Water and Wastewater. Food and Environmental Virology 1(1): 10-14.

13. Sahin AR (2020) 2019 Novel Coronavirus (COVID-19) Outbreak: A Review of the Current Literature. Eurasian Journal of Medical Investigation, 4(1): 1-7.

14. (2020) Study: COVID-19 may spread in several different ways | CIDRAP.

15. Zhang H, Kang Z, Gong H, Xu D, Wang J, et al. (2020) The digestive system is a potential route of 2019-nCov infection: a bioinformatics analysis based on single-cell transcriptomes. BioRxiv.

16. Thormar H, Isaacs CE, Brown HR, Barshatzky MR, Pessolano T (1987) Inactivation of enveloped viruses and killing of cells by fatty acids and monoglycerides. Antimicrobial Agents and Chemotherapy 31(1): 27-31.

17. KH Chan, JS Malik Peiris, SY Lam, LL M Poon, KY Yuen (2011) The Effects of Temperature and Relative Humidity on the Viability of the SARS Coronavirus. Advances in Virology p.7.

18. Nicosia LA, Rose JB, Stark L, Stewart MT (2001) A Field Study of Virus Removal in Septic Tank Drainfields. Journal of Environmental Quality 30(6): 1933-1939.

19. Libutti A, Gatta G, Gagliardi A, Vergine P, Pollice A, et al. (2018) Agroindustrial wastewater reuse for irrigation of a vegetable crop succession under Mediterranean conditions. Agricultural Water Management 196: $1-14$.

20. Arborea S, Giannoccaro G, de Gennaro B, Iacobellis V, Piccinni A (2017) Cost-Benefit Analysis of Wastewater Reuse in Puglia, Southern Italy. Water 9(3): 175.

21. Yépiz Gómez MS, Gerba CP, Bright KR (2013) Survival of Respiratory Viruses on Fresh Produce. Food and Environmental Virology 5(3): 150156.

22. Navarro T (2018) Water reuse and desalination in Spain - Challenges and opportunities. Journal of Water Reuse and Desalination 8(2): 153168.

23. Gallego Valero L, Moral Pajares E, Román Sánchez I, Sánchez Pérez J (2018) Analysis of Environmental Taxes to Finance Wastewater Treatment in Spain: An Opportunity for Regeneration? Water 10(2): 226.

24. Jodar Abellan A, López-Ortiz MI, Melgarejo Moreno J (2019) Wastewater treatment and water reuse in Spain. Current situation and perspectives. Water (Switzerland) 11(8): 1551-1574.

25. Water Challenges of Iran - Fanack Water.

26. Moghadam FM, Mahdavi M, Ebrahimi A, Tashauoei HR, Mahvi AH (2015) Feasibility Study of Wastewater Reuse for Irrigation in Isfahan , Iran 23(10): 2366-2373.

27. Collivignarelli MC, Abbà A, Padovani S, Frascarolo $M$, Sciunnach D, et al. (2015) Recovery of sewage sludge on agricultural land in lombardy: Current issues and regulatory scenarios. Environmental Engineering and Management Journal 14(7): 1477-1486.

28. Pourcher AM, Françoise PB, Virginie F, Agnieszka G, Vasilica S, et al. (2007) Survival of faecal indicators and enteroviruses in soil after landspreading of municipal sewage sludge. Applied Soil Ecology 35(3): 473479.

29. (2020) Wastewater Treatment Plants - DEP.

30. (2020) City unveils new design at wastewater treatment plant - Hunts Point Express.

31. Cheremisinoff NP (2002) Handbook of water and wastewater treatment technologies. Butterworth-Heinemann (Editor).

32. Wang XW, Li JS, Jin M, Zhen B, Kong QX, et al. (2005) Study on the resistance of severe acute respiratory syndrome-associated coronavirus. Journal of Virological Methods 126(1-2): 171-177.

33. (2020) RTI Center for Water Resources | RTI.

34. Centre HPS (2020) Advice note to EHS on COVID-19 in chlorinated drinking water supplies and chlorinated swimming pools. Health Service Executive.

35. Code of Federal Regulations, Title 40, Protection of Environment, Parts 136. Office of the Federal Register (USA) Staff, USA. Government Printing Office.

36. Kanna CR (2015) Inactivation of Viruses in water by chlorination using bacteriophages as model organisms.

37. Wati S, Robinson BS, Mieog J, Blackbeard J, Keegan AR (2019) Chlorine inactivation of coxsackievirus B5 in recycled water destined for nonpotable reuse. Journal of Water and Health 17(1): 124-136.

38. Nicosia LA, Rose JB, StarkL, Stewart MT (2001) A Field Study of Virus Removal in Septic Tank Drainfields. Journal of Environmental Quality 30(6): 1933-1939. 